\title{
Study on Tax Collection and Management of E-commerce in China
}

\author{
Zhu Pang \\ Shaanxi Institute of International Trade \& Commerce, Xianyang, Shaanxi, 712046
}

Keywords: E-commerce, Tax Collection, Management Trend

\begin{abstract}
As a new business model, e-commerce has not only changed the way of people's consumption, changed the business model, promoted economic growth, brought potential tax resources to all countries, and provided challenges to tax collection and management. E-commerce transaction scope of globalization, electronic means of payment, online business virtualization and other characteristics of the existing tax collection and management model does not meet the development of e-commerce. Chinese e-commerce in the last century began to develop in the 1990s, in the development of e-commerce scale, far less developed countries. Based on the analysis of the current situation of e - commerce tax collection and management in China, this paper puts forward the policy measures to improve the tax collection and management of e - commerce in China.
\end{abstract}

\section{Introduction}

E-commerce virtual management, trading venues virtual, digital products, global operations, for the physical transactions based on the current tax system and the impact of taxation, showing the lack of traditional tax collection and management model, the tax law is not on the electronic business figures The taxation of the products made by the taxpayer and the tax collection and management capacity of the tax authorities on the collection and management can not achieve the effect of levying all of the e-commerce, resulting in a large amount of tax loss. E-commerce products, digital and difficult to define the cross-border transactions, such as the risk of tax conflicts, making e-commerce tax collection and management issues become one of the international focus. On the one hand, the development of e-commerce led to the promotion of consumption levels to promote economic growth, to bring potential tax resources to governments. On the other hand, the characteristics of e-commerce makes the tax collection and management in the traditional business model difficult to apply to e-commerce, tax the main fuzzy, tax links scattered, tax location difficult to apply, the tax is unknown, cross-border jurisdictions and other issues on Chinese current Tax collection and management challenges. The 21st century is the era of e-commerce, China should be an objective view of the overall development of e-commerce, it is necessary to ensure the healthy development of e-commerce, but also a reasonable tax.

\section{E-Commerce to Chinese Tax Collection and Management of the Impact}

Tax laws and regulations directly responsible for tax units and individuals, known as the taxpayer. It is a prerequisite for the tax authorities to carry out tax collection and management. E-commerce operators, online registration site for business activities, for the fixed degree of dependence on the fixed place of business, e-commerce transactions, the two sides through the registration of the virtual account for online transactions, free from time and place restrictions can be 24 hours at any time The transactions on a global basis make it easy for both parties to hide the true identity and transaction and transaction behavior, making the taxpayer fuzzy. The tax authorities shall tax on the 
taxpayers who belong to their own jurisdiction, and the judgment of the jurisdiction shall be determined by the taxpayers in accordance with the physical space in which the taxpayer exists, and the taxpayers shall determine the jurisdiction in accordance with the place of registration, permanent establishment and transaction place, The income taxpayers in accordance with the residents jurisdiction and income jurisdiction for the collection of taxes, e-commerce registration IP address virtual business, physical transactions and business premises to reduce the dependence, making the tax authorities in determining the tax on the main difficulties.

The object of taxation refers to the object to which the tax law stipulates is the subject matter of the rights and obligations of both parties. Chinese turnover tax and income tax, respectively, provides a different tax object. The tax object of the turnover tax is the turnover of tangible goods and the turnover of the service. The taxable object of the income tax is the amount of taxpayer's income. In the e-commerce transactions not only include the sale of tangible products and the provision of labor services, but also includes the Internet's high-tech technology to produce new products - digital products (such as music, video, computer software, e-books, etc.) sales.

The tax location is the place where the taxpayer fulfills the tax liability and the withholding agent performs the duty of paying the withholding obligation. Different taxation tax location is different from the value-added tax, for example, the sale of goods in the territory of origin, or the provision of taxable services in the territory of China, the transaction of taxpayers in China bear the value of tax liability The The characteristics of e-commerce globalization trading have an impact on the determination of transnational tax jurisdictions. Under the traditional mode of trade, countries have their own tax jurisdictions, and foreign residents to go to their own country for life or business require special approval and obtain a permit. Taxpayers shall perform their tax liability in accordance with the tax jurisdiction of each country within different borders. E-commerce environment, the online business people can be unlimited through the network in the global cross-border free exchange, query information, e-commerce activities.

\section{Analysis of the Problems in the Tax Collection and Management of E-commerce}

At present, the current tax collection and management model should not meet the development of e-commerce. China should make use of the idea of e-commerce, establish a new mode of tax collection and management, start from the capital flow and information flow of e-commerce transactions, grasp its characteristics and laws, Around the traditional tax collection and management process, "people, financial, material" as the core, the use of computer networks, the establishment of various departments of information sharing mechanism to achieve e-commerce tax collection and management process information, electronic, network. At the same time, we must also develop relevant legal norms to ensure that the entire system is running safe, tight and efficient. In China has not yet introduced e-commerce tax policy, the study of how the tax collection and management of e-commerce is the focus of e-commerce tax organization.

Tax collection and management capacity refers to the ability of tax authorities to collect and manage taxes in a certain legal policy, system, economy and technology environment. In the current collection and management, the tax authorities mainly through the process to achieve "who taxes levy how much tax - how to organize tax collection and storage - whether the tax in full storage how to punish violations" and other purposes. Therefore, the collection and management capacity of the tax authorities mainly include: a. The ability to grasp the tax source (that is, by taxpayers for industrial and commercial registration within a certain period of time after the tax registration, with the business sector to obtain a list of taxpayers, to whom the tax); b. (The tax authorities to use their own means and institutional methods, the collection of taxes on the income of the tax); (c) the tax 
collection capacity (D) tax assessment and inspection capacity (the tax authorities through a certain technical methods and means to find whether the taxpayer has concealed income, virtual expenditure, false accounts, associated enterprises transfer profits in the tax declaration is not real (By law, the taxpayers to varying degrees of illegal acts of effective punishment, with a certain deterrent, to improve the taxpayer tax compliance).

In the face of e-commerce virtualization, electronic, global characteristics, tax authorities and taxpayers in the transaction information to further deepen the degree of asymmetry. First of all, in the taxpayer to grasp the link, some e-commerce taxpayers do not carry out tax registration to influence the tax authorities on the ability to grasp the tax source. Second, in determining the amount of tax, e-commerce taxpayers to conceal income without self-tax declaration or false tax returns and other acts will affect the tax authorities to determine the amount of taxpayer tax payable, thus affecting the tax collection capacity. Thirdly, in the process of tax assessment and tax inspection of e-commerce taxpayers, it is difficult for the tax authorities to obtain the real business information of taxpayers based on the characteristics of virtual place management, electronic transaction and online electronic transfer. The tax assessment ability and tax checking ability of e commerce tax collection and management are insufficient. Finally, there is no clear legal provision for e-commerce tax irregularities, resulting in some taxpayers mistakenly believe that online business tax violations will not be punished, the current tax laws for tax penalties for tax violations do not threaten e-commerce tax People, that the tax authorities can not find their tax violations, and then there are chances. With the development of technology in the field of e-commerce, tax collection and management in the field of e-commerce is weak, this phenomenon is not only detrimental to tax revenue growth, but also is not conducive to the sustainable development of e-commerce.

\section{E-commerce Tax Collection and Management Countermeasures}

In the process of tax collection and management of e-commerce, the tax authorities will encounter many on the normative issues of e-commerce, such as the legitimacy of the signature of electronic transactions, electronic payment issues, network privacy and confidentiality issues. In 1999, Australia established the Electronic Trading Act to increase the validation and regulatory framework for e-commerce transactions. China also needs to establish and improve the e-commerce-related legal norms e-commerce market. Strengthen the Internet security legislation. In view of the Internet trade secrets and personal secret disclosure problems, online fraud and pyramid selling issues such as the Internet security and trust of the key violations of the law to be legal norms, and be effectively punished. This is also the key to ensuring the healthy and orderly conduct of the e-commerce market.

In the process of e-commerce development, due to the virtual nature of e-commerce, global transactions make the existing tax policy in response to e-commerce taxation, especially direct e-commerce taxation, there are many legal gaps so that tax collection and management can not follow. E-commerce is mainly caused by the online transactions of direct e-commerce applicable tax fuzzy, indirect e-commerce transactions only online transactions and payment of payment and traditional business is different from the delivery of goods or through the offline logistics system transmission, The nature of sales has not changed, the collection of taxes can be levied in accordance with the traditional business model, the traditional business turnover tax tangible product transactions and services and services provided, the collection of value-added tax and business tax, e-commerce transactions with the nature of complete In accordance with the provisions of the existing tax system can be. 
The tax authorities in the e-commerce tax collection and management, in accordance with the provisions of the tax collection and management of tax collection and management. In the process of e-commerce development, new challenges are put forward for tax registration, invoice and voucher book management, tax filing and tax collection and inspection based on traditional business model. The current tax collection and management system and methods to deal with e-commerce virtual, electronic, globalization, the lack of transactions, therefore, the need for existing tax collection and management system to be improved. In the improvement of the collection and management system will encounter many problems need to collect the law to support, so that the tax authorities are tax evasion behavior law. Such as the tax authorities in the tax inspection, the right to check the information on the electronic transaction data should be provided in the legal provisions of the tax authorities have the right to follow the procedures for access and reproduction; taxpayers have to provide real electronic data tax information and financial information responsibility And the obligation; the same time, tax officers to check the taxpayer-related electronic information business data, in addition to taxpayers violations, inspectors have the obligation to taxpayer business information confidential.

\section{Conclusion}

Enterprises can use e-commerce to reduce transaction costs, rational allocation of resources, improve efficiency, promote the rapid flow of funds, save money to expand the scale of enterprise development and improve competitiveness. The current tax policy and the collection and management system is basically based on the traditional business design, e-commerce fast, efficient, virtual features, making the enterprise in the course of the transaction may have the possibility of tax evasion. For people shopping through the Internet, online shopping is cheap, convenient, fast, more optional goods, you can cross-border purchase of goods such as price and geographical advantages, making more and more people are more willing to choose to shop online The

\section{References}

[1] Li Yehua. Foreign electronic commerce tax research summary [J]. Finance sector, 2015 (02)

[2] Zhang Wei, Ye Chengang, Xu Wei. C2C e-commerce tax collection and management issues [J]. Tax Research, 2014 (10)

[3] Li Jianying, Li Tingting, Xie Sibo. Construction of "capital flow" control based e-commerce tax collection and management model [J]. Economics and Management Review, 2014 (03)

[4] Jiang Zhen. The e-commerce tax policy of some thinking [J]. Tax economy research, 2013 (06)

[5] Li Heng, Wu Weiku, Zhu Qian. American e-commerce tax policy and game behavior of Chinese enlightenment [J]. Tax Research, 2014 (02) 